\title{
Autoantibodies to the Insulin Receptor
}

\author{
EFFECT ON THE INSULIN-RECEPTOR INTERACTION IN
}

IM-9 LYMPHOCYTES

\author{
JefFrey S. Flier, C. Ronald Kahn, David B. Jarrett, and Jesse Roth, \\ Diabetes Branch, National Institute of Arthritis, Metabolism, and Digestive \\ Diseases, National Institutes of Health, Bethesda, Maryland 20014
}

A BSTRACT The serum of some patients with insulin-resistant "diabetes" contains antibodies that bind to and block the cell membrane receptors for insulin. In this report, we have characterized the effects of the antireceptor antibodies on the interaction of ${ }^{125} \mathrm{I}$-insulin with its receptor on the human lymphoblastoid cell line IM-9. Up to $95 \%$ of specific insulin binding can be inhibited by pretreatment of the cells with these immunoglobulins. The onset of the inhibitory effect is time- and temperature-dependent, and the effect is reversed extremely slowly if the cells are suspended in a large excess of antibody-free buffer. These features of antibody binding can be easily distinguished from those for insulin binding to its receptor. The inhibitory effect of the antibodies can be reversed by exposure of the cells to conditions known to elute surface immunoglobulins.

The three antireceptor sera studied appear to alter the insulin-receptor interaction in different ways. Two antisera markedly reduce receptor affinity through combined effects on the insulin association and dissociation rates, and, additionally, have smaller effects on available receptor number. A third antiserum primarily affects available receptor number and has little effect on receptor affinity. All three antisera inhibit the capacity of insulin to promote negatively cooperative site-site interactions among insulin receptors. The data suggest that these autoantibodies to the insulin receptor bind to different determinants on the receptor and may therefore be useful as

Presented in part at the Annual Meeting of the American Society for Clinical Investigation, Atlantic City, N. J., 3 May 1976.

Dr. David B. Jarrett is a recipient of a Clinical Sciences Fellowship from the National Health and Medical Research Council of Australia.

Received for publication 24 November 1976 and in revised form 8 May 1977. unique probes of insulin receptor structure and function.

\section{INTRODUCTION}

We have recently described two clinical syndromes characterized by severe insulin resistance, acanthosis nigricans, and a marked defect at the level of the membrane receptor for insulin (1). These two syndromes, referred to as types $\mathrm{A}$ and $\mathrm{B}$, can be distinguished on clinical grounds, and by the fact that type B patients have a circulating inhibitor of insulin receptor binding (2). In a previous report, we have shown that the circulating inhibitors in these patients are polyclonal immunoglobulins, primarily of the IgG class, and that their inhibitory activity is mediated through the $F\left(a b^{\prime}\right)_{2}$ portion of the molecule (3). Further, several lines of evidence strongly suggest that these antibodies act by binding directly to determinants on, or intimately linked to, the insulin receptor molecule (2-4). Thus, these immunoglobulins may be considered to be "antireceptor antibodies" such as those which have been proposed as etiologic factors in Graves' disease (5) and myasthenia gravis (6).

Our initial description and characterization of these antibodies was based on a simple assay in which normal cells or membranes were exposed to serum or immunoglobulin fractions for $1 \mathrm{~h}$ at $4^{\circ}$ or $22^{\circ} \mathrm{C}$, thoroughly washed, and then exposed to ${ }^{125}$ I-insulin for binding assay $(2,3)$. In this report, we explore in more detail the effects of these antireceptor antibodies on ${ }^{125} \mathrm{I}$-insulin binding to its receptors on the human lymphoblastoid cell of the IM-9 line. We report data on $(a)$ the kinetics of onset and reversal of antibody action, (b) the variable effects of these antibodies on the kinetics of insulin association, dissociation, and insulin-induced negative cooperativ- 
ity, and $(c)$ the effects of these antibodies on the affinity and number of residual insulin receptors. Taken together, these data indicate that antibodies to the insulin receptor impair insulin binding by a variety of mechanisms, and that sera from different patients may differ in the precise locus of their actions.

\section{METHODS}

Human lymphoblastoid cells (IM-9), maintained in continuous culture in plastic flasks, were grown to stationary phase at $37^{\circ} \mathrm{C}$ in Eagle's Minimum Essential Medium (National Institutes of Health Media Unit) supplemented with $10 \%$ fetal calf serum, penicillin, and streptomycin. Glutamine $(0.26 \mathrm{mg} / \mathrm{ml})$ was added to the medium just before transfer of the cells on the day of feeding. Cells were split twice a week and fresh media was added. Viability of cells was monitored by trypan blue dye exclusion and was always $>90 \%$. Previous studies (7) have shown that insulin receptors on these cells have binding properties essentially identical to those of insulin receptors on more classic targets of insulin action such as liver (8) and fat (9). Porcine insulin (Eli Lilly Co., Indianapolis, Ind.) was iodinated to a sp act of $100-200 \mu \mathrm{Ci} / \mu \mathrm{g}$ by a modification of the chloramine-T method (10).

All sera were obtained after an overnight fast and were stored at $-20^{\circ} \mathrm{C}$ until use. The notation for identification of sera corresponds to that employed in a previous publication (1).

Preincubation with serum. IM-9 cells were sedimented and resuspended at a concentration of $15 \times 10^{6} / \mathrm{ml}$ in an assay buffer containing $100 \mathrm{mM}$ Hepes, $120 \mathrm{mM} \mathrm{NaCl}$, $1.2 \mathrm{mM} \mathrm{MgSO}_{4}, 2.5 \mathrm{mM} \mathrm{KCl}, 10 \mathrm{mM}$ glucose, $1 \mathrm{mM}$ EDTA, and $1 \%$ bovine serum albumin, pH 7.6. Patient or control sera were diluted with phosphate-buffered saline (PBS), ${ }^{1} \mathrm{pH} 7.6$, and then incubated for various periods at the indicated temperatures with an equal volume of the cell suspension to give the final serum dilution as indicated in the legend to the figures. After preincubation, cells were washed three times with 3 vol of PBS and resuspended in assay buffer at a concentration of $15 \times 10^{6}$ cells/ml for insulin binding study. Previous studies have shown (2) that exposure of cells to normal serum to which high concentrations of insulin $(50 \mathrm{ng} / \mathrm{ml})$ have been added causes no reduction of subsequent ${ }^{125}$ I-insulin binding under these conditions of preincubation and extensive washing.

Insulin binding studies. After preincubation of cells as described, the binding of ${ }^{125} \mathrm{I}$-insulin to these cells was determined in a variety of ways: $(a)$ the effects of duration and temperature of serum preincubation on binding inhibition; $(b)$ the time-course and temperature dependence of recovery of binding in the absence of serum; $(c)$ the reversal of binding inhibition by acid wash; $(d)$ the effect of serum treatment on association rate of ${ }^{125} \mathrm{I}$-insulin; (e) the effect of serum treatment on dissociation rate of ${ }^{125}$ I-insulin in the presence and absence of unlabeled insulin; $(f)$ the effect of serum treatment on steady-state insulin binding. The details of these procedures are contained within the legends to the figures.

Data analysis. The data on steady-state binding of ${ }^{125}$ I-insulin to its receptor is presented in three ways, each of which emphasizes different quantitative aspects of the binding interaction. (a) The percent of total radioactivity

${ }^{1}$ Abbreviations used in this paper: $\mathrm{B} / \mathrm{F}$, bound/free; PBS, phosphate-buffered saline; $R_{0}$, receptor concentration. that is specifically bound to receptors is plotted as a function of log total insulin concentration. This most closely represents the actual experimental results. (b) Bound/free of ${ }^{125} \mathrm{I}$-insulin $(\mathrm{B} / \mathrm{F})$ is plotted as a function of bound (B) hormone (Scatchard plot; reference 11). The total binding capacity or the total concentration of receptor sites $\left(R_{0}\right)$ is derived from the point where the extrapolation of the curve intersects the horizontal axis. Analysis of receptor affinity in this system is rendered complex by the curvilinear Scatchard plot which is obtained for binding of insulin to its receptor. Experimental data have shown that this curvilinear Scatchard plot is due, at least in part, to continuous reduction of affinity with increasing occupancy of receptors (i.e. negative cooperativity [12]). For this reason, we have also expressed the data in a third graphic manner, recently described by De Meyts and Roth (13). (c) This plot expresses the relationship between receptor affinity for insulin $(\bar{K})$ at a given hormone concentration and the fractional occupancy of total receptors at the same hormone concentration $(\bar{Y})$. In the equation $\bar{K}_{i}=(\mathrm{B} / \mathrm{F}) /$ $\mathrm{R}_{\mathrm{o}}-\mathrm{B}, \bar{K}_{i}$ is the "average affinity" at any point $(i)$ on the Scatchard curve, where $B_{i}$ is the concentration of bound hormone and $(B / F)_{i}$ is the bound/free hormone at that point. When the "average affinity" $(\bar{K})$ is plotted as a function of $\log$ of the fractional occupancy of the receptor ( $\bar{Y}$ or $B / R_{0}$ ), the plot displays the average affinity of the receptor at all levels of receptor occupancy and is referred to as the "average affinity profile" (13). In this analysis, the limiting high affinity state, obtained at low levels of receptor occupancy, is designated $\bar{K}_{e}$ (affinity of the empty receptor), and the limiting low affinity state, obtained at high levels of receptor occupancy, is $\bar{K}_{f}$ (affinity of the filled receptor).

\section{RESULTS}

Effect of preincubation with undiluted sera on subsequent insulin binding. Undiluted sera from six patients with extreme insulin resistance (types A and B) were assayed for ability to inhibit insulin binding to IM-9 lymphocytes after preincubations of increasing durations at $37^{\circ} \mathrm{C}$ (Fig. 1). The two sera (B-2 and B-3) from the type $B$ patients who displayed the greatest clinical insulin resistance produced nearly maximal inhibition after $5 \mathrm{~min}$ of preincubation. With these sera, 96 and $90 \%$ of specific binding were prevented, respectively. Serum B-1, obtained from a patient with less severe insulin resistance, produced a time-dependent increase in inhibition, with maximal effect not yet obtained after $3 \mathrm{~h}$.

Sera A-1, A-2, and A-3, obtained from patients with insulin resistance and a severe insulin receptor deficiency with an apparently distinct etiologic basis (1), caused no significant inhibition of binding after $3 \mathrm{~h}$ of preincubation at $37^{\circ} \mathrm{C}$. It is notable that serum insulin concentrations in these type A patients were comparable to those of type $B$ patients, thus providing an internal control against a possible role for insulin in the production of the observed inhibitory effect.

Effect of duration and temperature of preincubation on subsequent insulin binding. To enable a comparison of the temperature dependence and time- 


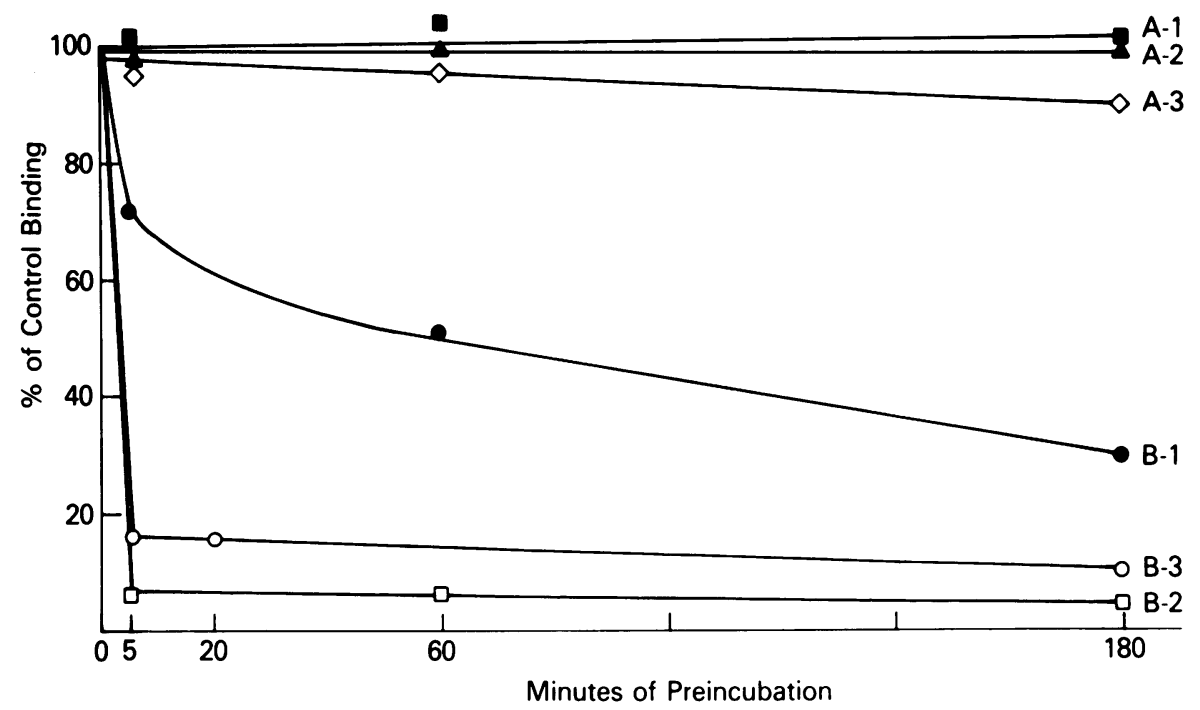

FIGURE 1 Effect of concentrated sera on insulin binding. $3 \times 10^{6} \mathrm{IM}-9$ lymphocytes in $0.2 \mathrm{ml}$ of assay buffer were incubated at $37^{\circ} \mathrm{C}$ with $0.2 \mathrm{ml}$ of sera ("preincubated" at a final dilution of $1: 2$ ) for time-periods as indicated on the horizontal axis. After the preincubation, cells were washed three times with $1 \mathrm{ml}$ of $\mathrm{PBS}, \mathrm{pH} \mathrm{7.6}$, at $22^{\circ} \mathrm{C}$, and then resuspended in tubes containing $0.5 \mathrm{ml}$ of assay buffer to which was added $100 \mathrm{pg}$ of ${ }^{125} \mathrm{I}$-insulin. One set of tubes contained, in addition, $10 \mu \mathrm{g} / \mathrm{ml}$ of unlabeled insulin. Cells and insulin were incubated for $90 \mathrm{~min}$ at $15^{\circ} \mathrm{C}$, after which duplicate 200 $\mu \mathrm{l}$ samples were transferred and centrifuged through $100 \mu \mathrm{l}$ of cold buffer in a Beckman microfuge (Beckman Instruments, Inc., Cedar Grove, N. J.) for $1 \mathrm{~min}$, the supernate was aspirated, and the ${ }^{125} \mathrm{I}$ insulin bound to the pellet was determined. Specific ${ }^{125} \mathrm{I}$-insulin binding was considered to be the difference between binding in the absence and presence of $10 \mu \mathrm{g} / \mathrm{ml}$ of unlabeled insulin. The percent of control binding was calculated by dividing the percent specifically bound to antibodytreated cells by the percent specifically bound to buffer-treated cells and multiplying by 100 .

course of onset of inhibitory effect in these three sera, cells were preincubated with dilutions of sera designed to produce comparable reductions of binding (about $50 \%$ of control; Fig. 2). These dilutions were $1: 4,1: 4,000$, and $1: 80$ for sera B-1, B-2, and B-3, respectively. Under these conditions, sera $\mathrm{B}-2$ and $\mathrm{B}-3$ showed rates of onset of inhibition that were greater at $37^{\circ} \mathrm{C}$ than at $22^{\circ} \mathrm{C}$, which in turn were greater than that at $4^{\circ} \mathrm{C}$. With serum B- 1 , there was a different temperature dependence, with $22^{\circ}>37^{\circ}>4^{\circ} \mathrm{C}$. Because maximum inhibition had not been reached at every temperature by $180 \mathrm{~min}$, it is uncertain whether temperature affected only rate of onset of inhibition (and presumably antibody binding) or maximal extent of inhibition as well. It should be noted that sera A-1, A-2, and A-3, which produced no binding inhibition at $37^{\circ} \mathrm{C}$ (Fig. 1), also had no effect at $4^{\circ}$ or $22^{\circ} \mathrm{C}$ (data not shown).

Reversal of inhibitory effects. When compared to the time-course of onset of antibody inhibition of insulin binding, cells treated with serum B-2 were slow to recover insulin binding when washed and re-

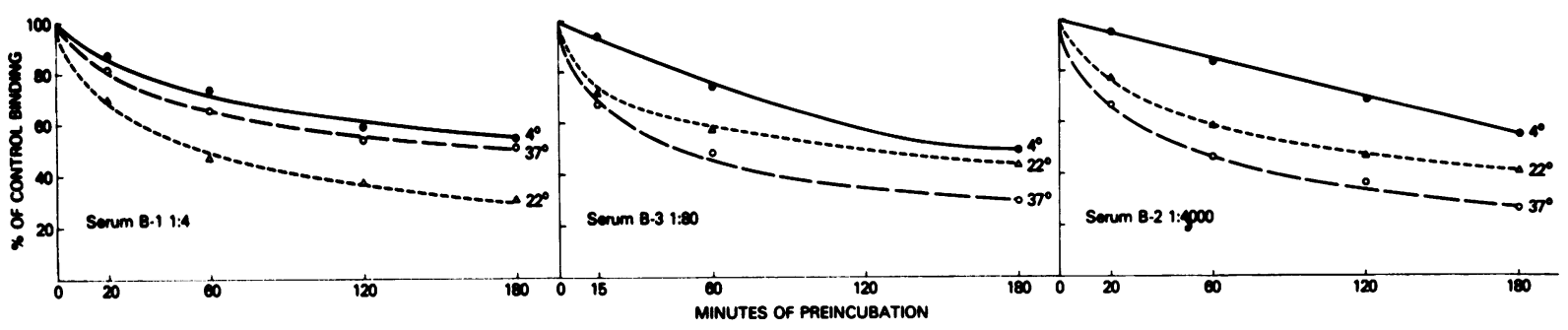

Figure 2 Effect of duration and temperature of preincubation on subsequent insulin binding. $3 \times 10^{6} \mathrm{IM}-9$ lymphocytes in $0.2 \mathrm{ml}$ of assay buffer were incubated at $4^{\circ}, 22^{\circ}$, and $37^{\circ} \mathrm{C}$ with $0.2 \mathrm{ml}$ of diluted serum as shown (diluted in PBS), for varying periods of time. After preincubation, cells were washed, resuspended, assayed for insulin binding, and the data were calculated as described in the legend to Fig. 1. 


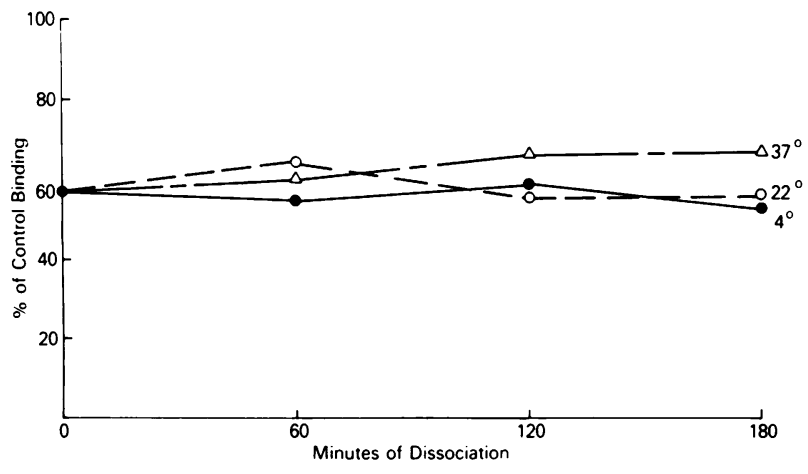

FIGURE 3 Reversal of antireceptor antibody effect by dilution. $30 \times 10^{6}$ IM-9 lymphocytes in $1.5 \mathrm{ml}$ of assay buffer were incubated at $22^{\circ} \mathrm{C}$ for $60 \mathrm{~min}$ with either $1.5 \mathrm{ml}$ of a 1:2,000 dilution of serum B-2 (to give a final dilution of $1: 4,000)$ or with an equal volume of assay buffer alone. After preincubation, cells were washed three times with $6 \mathrm{ml}$ of $\mathrm{PBS}$ at $22^{\circ} \mathrm{C}$, and then resuspended in $3 \mathrm{ml}$ of assay buffer at $4^{\circ} \mathrm{C}$. Duplicate $100-\mu l$ samples of the resuspended cell suspensions were added to tubes containing $5.0 \mathrm{ml}$ of assay buffer at $37^{\circ}, 22^{\circ}$, or $4^{\circ} \mathrm{C}$. After 1,2 , or $3 \mathrm{~h}$, cells were sedimented, and the pellet was resuspended in $0.5 \mathrm{ml}$ of assay buffer for ${ }^{125}$ I-insulin binding assay as described in the legend to Fig. 1. Results, expressed as percent of control binding at each time-point, were calculated by dividing the percent bound to serum-treated cells, by the percent bound to identically handled buffer-treated cells and multiplying by 100 .

suspended in a large excess of buffer (Fig. 3). Very similar results were obtained with sera B-1 and B-3 (data not shown). When cells were diluted in buffer at $4^{\circ}$ or $22^{\circ} \mathrm{C}$, no recovery of insulin binding was detectable at $3 \mathrm{~h}$, and at $37^{\circ} \mathrm{C}$ binding increased by only $10 \%$ after $3 \mathrm{~h}$. The very slow rate of recovery of insulin binding after antibody treatment should be compared to the much more rapid recovery of insulin binding when insulin itself is dissociated from its receptor on these or other cells (7).

To further explore the reversible nature of antibody-mediated binding inhibition, we exposed normal cells and cells which had been antibody-treated to wash conditions known to elute antibodies from cell membranes (14; Fig. 4). Cells in which insulin binding had been reduced by preincubation with antibody showed a threefold increase of insulin binding after acid wash, suggesting that the inhibition of binding caused by the antibody can be reversed after the antibody is eluted. The level of binding did not return entirely to normal, however, probably as a result of damage to the receptor caused by the acid conditions of the wash. Brief exposure of normal cells to the same wash conditions resulted in a reduction in binding to the same level as observed in the antibody-treated cells which had been acid washed. In a previous study, with ${ }^{125}$ I-labeled antibodies from this serum (4), we have demonstrated directly that the antireceptor antibodies are eluted from the cells by acid wash, and that these eluted antibodies are enriched for specific binding to the insulin receptor.

Effect of preincubation with serum on ${ }^{125}$ I-insulin binding at steady state. To examine the nature of the binding inhibition produced by antireceptor antibodies, cells were preincubated with sera or buffer and washed as indicated, following which steady state insulin binding was measured over a wide range of insulin concentrations. When $\mathrm{B} / \mathrm{F}$ of the labeled hormone is plotted as a function of total hormone concentration (Fig. 5), the curves for the serumtreated cells show a reduced $B / F$ compared to buffertreated cells over the entire range of insulin concentrations, from 0.2 to $100 \mathrm{ng} / \mathrm{ml}$. When the $\mathrm{B} / \mathrm{F}$ for the labeled hormones is expressed as a function of total hormone bound (B), i.e. Scatchard plot, curvilinear

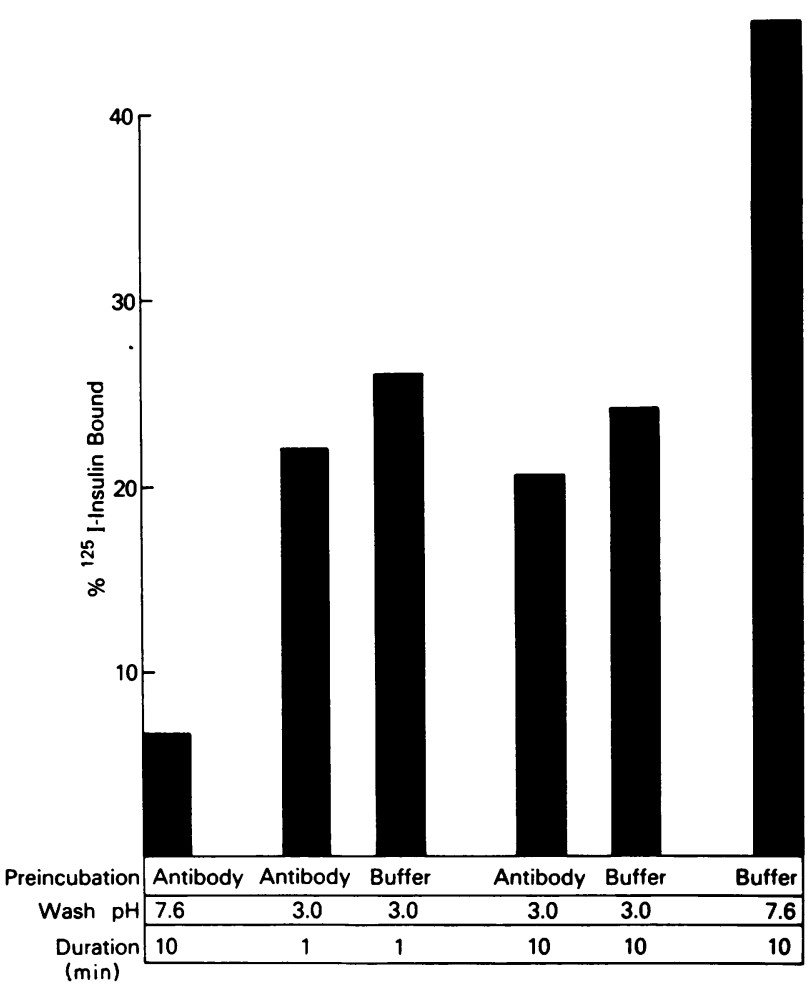

FIGURE 4 Reversal of antireceptor antibody effect by acid wash. $3 \times 10^{6}$ IM-9 lymphocytes in $0.2 \mathrm{ml}$ of assay buffer were incubated at $22^{\circ} \mathrm{C}$ for 60 min with $0.2 \mathrm{ml}$ of serum B-2 diluted 1:100 in assay buffer or with buffer alone. After preincubation, cells were washed three times in $1 \mathrm{ml}$ of PBS pH 7.6 at $22^{\circ} \mathrm{C}$. After the third wash, cell pellets were resuspended in $1.0-\mathrm{ml}$ vol of either a glycine $\mathrm{HCl}$ buffer, pH 3.0, that contained $3 \mathrm{mg} / \mathrm{ml}$ bovine serum albumin (14) or assay buffer, $\mathrm{pH} 7.6$, for 1 or $10 \mathrm{~min}$, as indicated. Cells were then sedimented, washed twice in $2 \mathrm{ml}$ of assay buffer, and finally resuspended in $0.5 \mathrm{ml}$ of assay buffer for insulin binding assay as described in the legend to Fig. 1. Results are expressed as the percent of ${ }^{125} \mathrm{I}$ insulin bound in each case. 


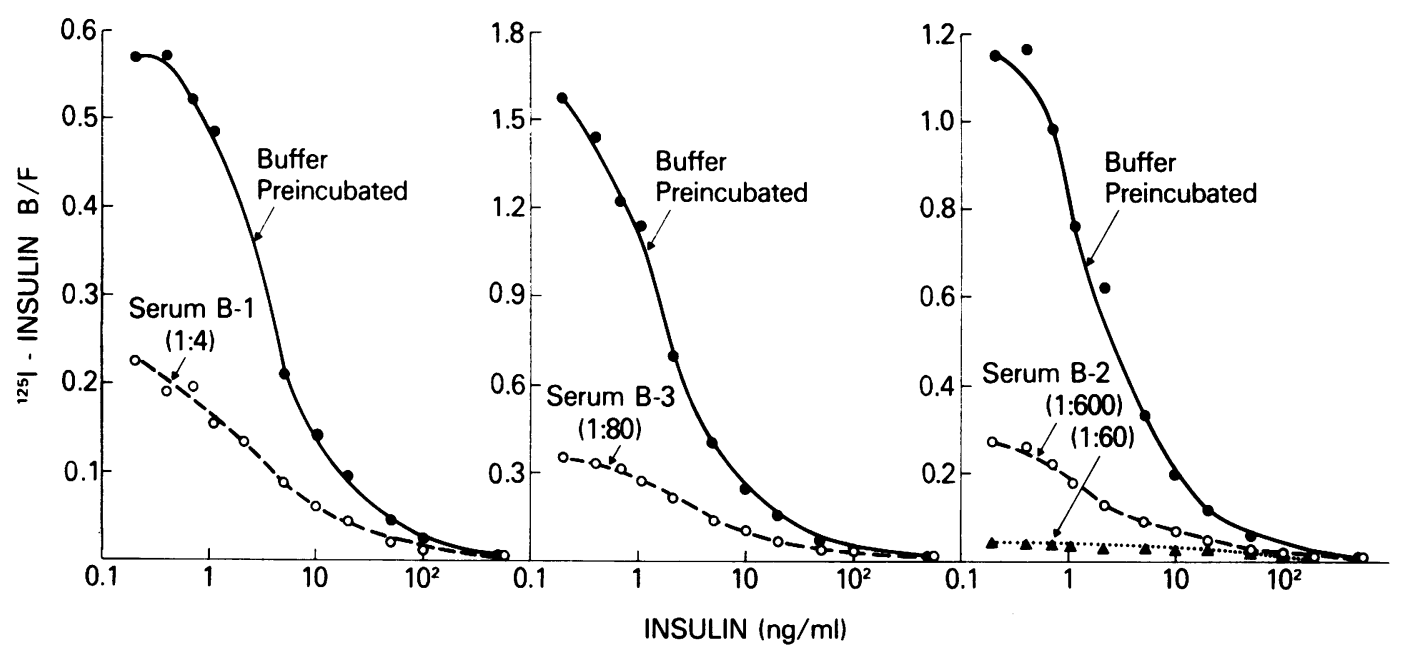

FIGURE 5 Effect of antireceptor antibody on insulin binding at steady state. $3 \times 10^{6}$ IM-9 lymphocytes in $0.2 \mathrm{ml}$ of assay buffer were incubated at $22^{\circ} \mathrm{C}$ for $60 \mathrm{~min}$ with $0.2 \mathrm{ml}$ of dilutions of each sera, to give the final dilutions as indicated. Cells were then washed as described in the legend to Fig. 1, and the pellets were resuspended in tubes containing $0.5 \mathrm{ml}$ of assay buffer, $100 \mathrm{pg}$ of ${ }^{125}$ I-insulin, and different amounts of unlabeled insulin, as seen on the horizontal axis. After incubation at $15^{\circ} \mathrm{C}$ for $90 \mathrm{~min}$, duplicate $200-\mu \mathrm{l}$ samples were removed, and the ${ }^{125}$ I-insulin bound to the pellet was determined as described in the legend to Fig. 1. B/F of the labeled hormone is plotted as a function of the total insulin in each tube.

plots are obtained (Fig. 6). As shown by De Meyts et al. (12), these curvilinear plots are consistent with insulin binding sites that exhibit receptor sitesite interactions of the negative cooperative type. As discussed in Methods, the total binding capacity or receptor concentration $\left(R_{0}\right)$ can be calculated from the intercept of the curve with the horizontal axis. As seen in Fig. 6 and Table $I$, serum treatment does, in each case, result in some reduction in the calculated $R_{0}$. If the action of these antibodies was solely to decrease the number of functional receptors, without altering receptor affinity or site-site interactions, we would expect a parallel leftward shift of the Scatchard curve. This was indeed the case with serum B-1, which produced a nearly parallel leftward shift of the Scatchard curve (Fig. 6). With serum B-2 and B-3, however, the reduction of receptor number was not associated with a parallel shift in the Scatchard plot, implying an additional effect on receptor affinity to account for the total

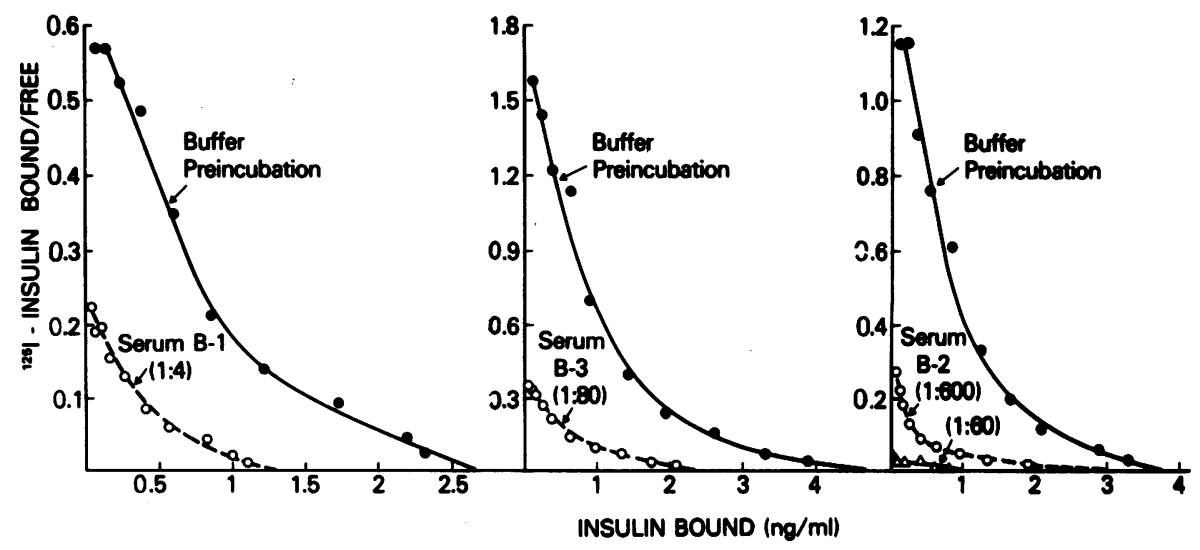

FIGURE 6 Effect of antireceptor antibody on Scatchard plot for ${ }^{125}$ I-insulin binding. The data obtained from the experiment in Fig. 5 is plotted by the method of Scatchard as B/F hormone on the vertical axis versus the hormone bound in nanograms per milliliter on the horizontal axis. 
TABLE I

Effect of Serum Pretreatment on Subsequent Binding of ${ }^{125}$ I-Insulin to IM-9 Cells

\begin{tabular}{llrcc}
\hline \multirow{2}{*}{ Serum } & Dilution & $\begin{array}{c}\text { B/F at } \\
\text { low (H) }\end{array}$ & \multicolumn{1}{c}{$\mathbf{R}_{\mathbf{0}}$} & $\bar{K}_{e}$ \\
\hline & & \multicolumn{3}{c}{ \% of control } \\
B-1 & $1: 4$ & 38 & 50 & 90 \\
B-2 & $1: 600$ & 25 & 60 & 39 \\
B-2 & $1: 60$ & 4 & 19 & 11 \\
B-3 & $1: 80$ & 23 & 55 & 32 \\
\hline
\end{tabular}

The binding of ${ }^{125} \mathrm{I}$-insulin to IM-9 lymphocytes after preincubation with sera (data from Figs. 5-7) is expressed as percent of control binding, for $(a) \mathrm{B} / \mathrm{F}$ at hormone $(\mathrm{H})$ concentration, $(b)$ receptor concentration $\left(R_{0}\right)$, and $(c)$ average affinity at low receptor occupancy $\left(\bar{K}_{e}\right)$.

reduction in steady-state binding observed at low hormone concentration.

To help clarify this parameter, we have used the average affinity profile (13), in which the average affinity of the system is plotted as a function of receptor occupancy (Fig. 7). With this graphic method it is apparent that the average affinity of the insulin receptor is reduced, to variable degrees by different sera, particularly at low degrees of receptor occupancy. The limiting high affinity obtained at low occupancy, $\bar{K}_{e}$, ranges from $11 \%$ of control with high concentrations of serum B-2 to $90 \%$ of control for serum B-1 (Table I). With increasing saturation by insulin, the $\bar{K}$ of the antibody-treated cells approaches that of controls, and the two are very similar at $\bar{K}_{f}$, the limiting low affinity. Thus, the overall reduction in steady-state binding caused by these antibodies is the result of variable reductions of both receptor number and affinity. The effect of serum B-1 is primarily on receptor number, and the effect of serum B-2 and B-3 is primarily on receptor affinity, with a lesser effect on receptor number.

Effect of serum on association and dissociation of ${ }^{125}$ I-insulin. The association rates of ${ }^{125}$ I-insulin to cells pretreated with each sera were reduced when compared to control, and these effects were related to the concentrations of serum employed (Fig. 8). With each serum, the reduced association rate could result from reduction of receptor concentration, as well as from an alteration in association rate constant. When the data for association of ${ }^{125}$ I-insulin to cells treated with serum B-2 was fitted to a second order rate equation, a linear plot was obtained over the first $10 \mathrm{~min}$ of association (Fig. 9). The calculated rate constants $(k)$ were seen to be reduced by serum treatment; with the highest serum concentration, a fivefold reduction of $k$ was produced. Thus, reduction of association rate constant for insulin binding would appear to contribute to the reduced affinity of hormone binding to cells pretreated with serum B-2.

To assess the possibility that binding of antibody to the receptor could induce the phenomenon of negative cooperativity, and thereby account in part for the reduced affinity of antibody-treated cells for insulin, we examined the effect of purified antibody on the dissociation of prebound ${ }^{125}$ I-insulin (Table II). Addition to the dilution medium of an amount of antibody (from serum B-2) sufficient to cause an $80 \%$ reduction of tracer insulin binding had no effect on the dissociation rate of ${ }^{125} \mathrm{I}$-insulin bound to control cells when compared to the dissociation rate observed by dilution alone. This contrasts markedly with the ability of unlabeled insulin in the dilution medium to accelerate the dissociation of bound hor-

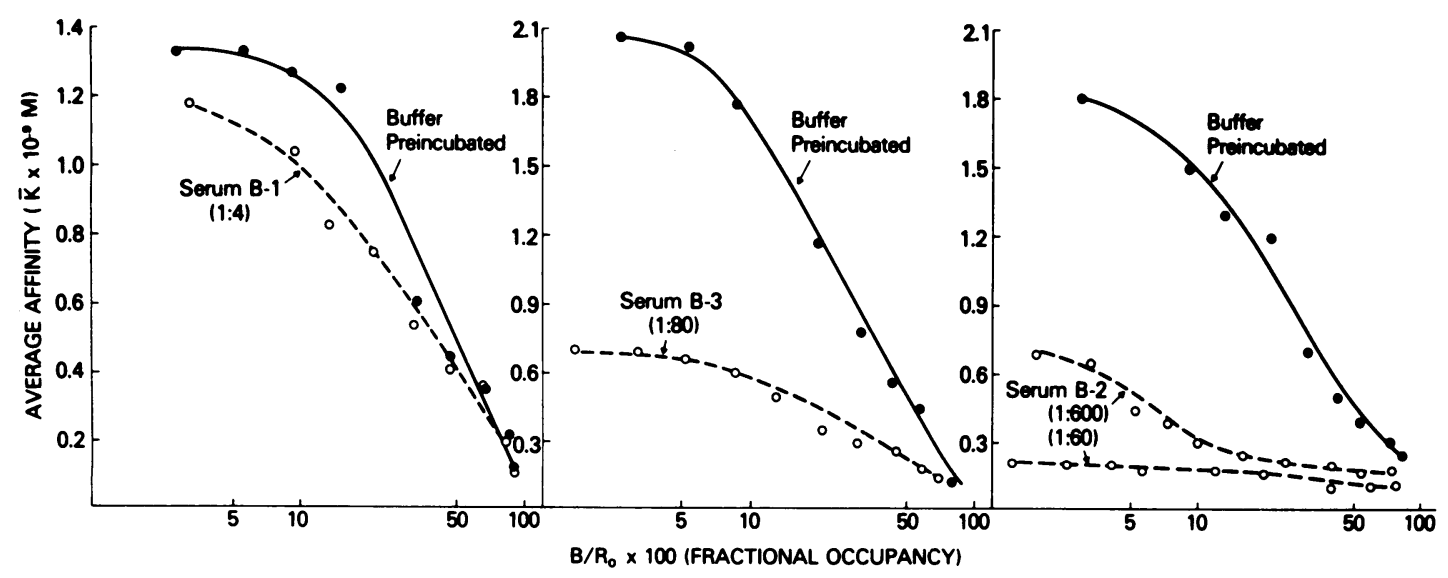

FIGURE 7 Effect of antireceptor antibody on average affinity profile of ${ }^{125}$ I-insulin binding. The data from the experiment in Fig. 5 is plotted as $\left.(B / F) / R_{0}-B\right)$, i.e., the average affinity $(\bar{K})$ vs. $B / R_{0}$, i.e., the percentage of total receptors that are occupied $(\bar{Y})$. 


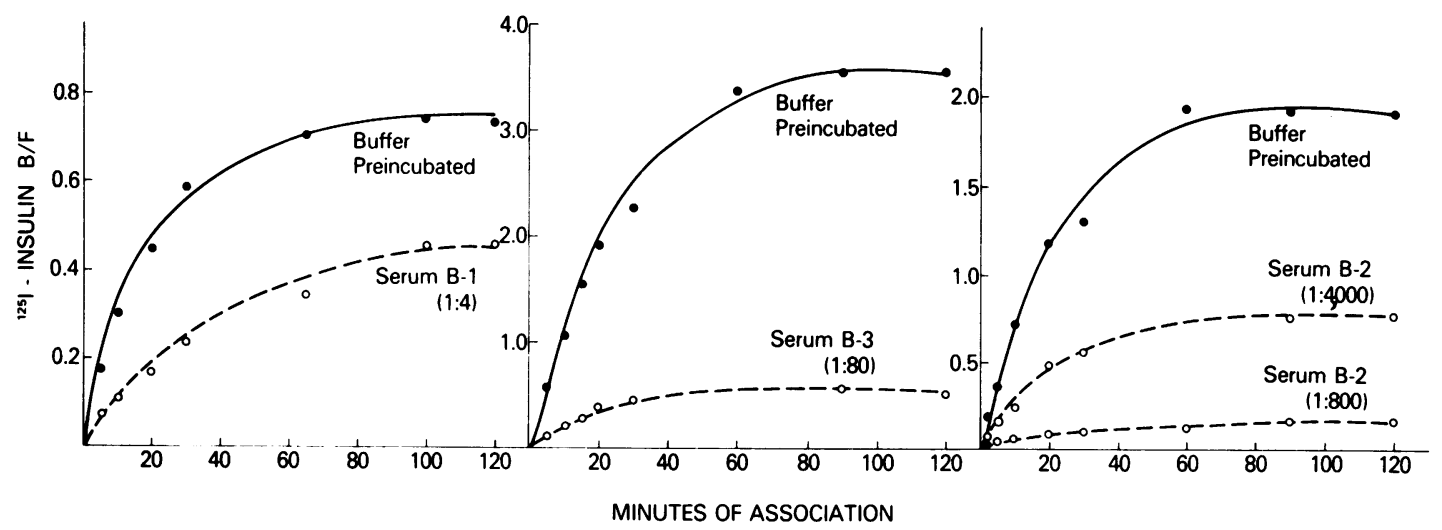

FIGURE 8 Effect of antireceptor antibody on association of ${ }^{125}$ I-insulin. $30 \times 10^{6}$ IM-9 cells in $2.0 \mathrm{ml}$ of assay buffer were incubated for $1 \mathrm{~h}$ at $20^{\circ} \mathrm{C}$ with $2.0 \mathrm{ml}$ of serum to produce the indicated dilution, or with buffer. After three washes with $10 \mathrm{~cm}^{3}$ of buffer at $4^{\circ} \mathrm{C}$, cells were resuspended in $2.0 \mathrm{~cm}^{3}$ of assay buffer at $15^{\circ} \mathrm{C}$. In each case, $500 \mathrm{pg}$ of ${ }^{125} \mathrm{I}-$ insulin was added both in the presence and absence of $10 \mu \mathrm{g} / \mathrm{ml}$ unlabeled insulin. At indicated time-points, duplicate $100-\mu \mathrm{l}$ samples were removed and sedimented through $200 \mu \mathrm{l}$ of cold buffer in microfuge tubes, the supernates were aspirated, and the ${ }^{125} \mathrm{I}-$ insulin bound to the pellets determined. Specific $B / F$ of the labeled hormone on the vertical axis is plotted as a function of time.

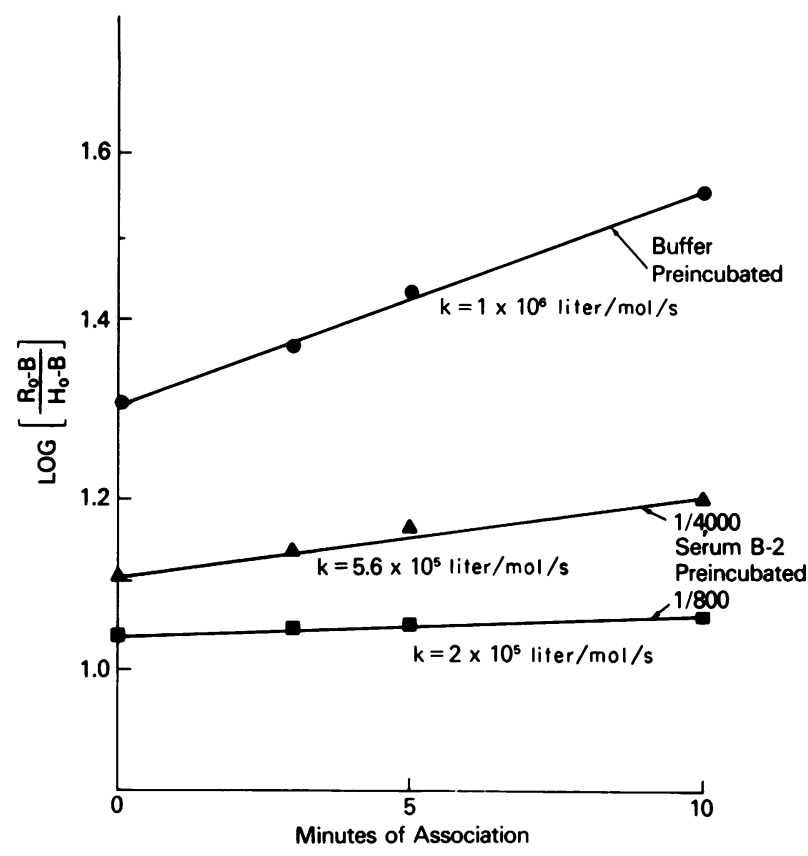

FIGURE 9 The data for the binding of ${ }^{125}$ I-insulin to IM-9 cells with and without pretreatment with serum B-2 (Fig. 8) was applied to the second order rate equation

$$
\frac{1}{(b-a)} \cdot \ln \frac{a(b-x)}{b(a-x)}=k t,
$$

where $b=\mathbf{R}_{0}, a=\mathbf{H}_{0}$, and $x=$ bound hormone. The total $\mathbf{R}_{0}$ after treatment with buffer or serum in each case was determined at steady state using Scatchard analysis in a separate experiment (data not shown). The plots were linear over the first $10 \mathrm{~min}$ of association, and the rate constant $(k)$ was calculated by solution of the preceding equation. mone under identical conditions. In this experiment, the accelerated dissociation of bound insulin by unlabeled hormone is indicative of the negatively cooperative site-site interactions that are a consequence

TABLE II

Effect of Insulin and Antibody to the Insulin Receptor on Dissociation of ${ }^{125}$ I-Insulin from IM-9 Lymphocytes

\begin{tabular}{lccc}
\hline \multicolumn{1}{c}{ Dilution medium } & 30 min & 60 min & 90 min \\
\hline & \multicolumn{3}{c}{$\begin{array}{c}\text { \% of counts remaining after } \\
\text { increasing periods of } \\
\text { dissociation }\end{array}$} \\
Buffer & 63 & 55 & 47 \\
$\begin{array}{l}\text { Buffer + antibody to the insulin } \\
\text { receptor }\end{array}$ & 65 & 60 & 51 \\
Buffer + insulin $(0.167 \mu \mathrm{M})$ & 27 & 21 & 17 \\
\hline
\end{tabular}

$30 \times 10^{6}$ IM-9 lymphocytes in $1 \mathrm{ml}$ of assay buffer were incubated with $400 \mathrm{pg}$ of ${ }^{125} \mathrm{I}$-insulin at $15^{\circ} \mathrm{C}$ for $90 \mathrm{~min}$. Cells were sedimented and then resuspended in $1.0 \mathrm{ml}$ of fresh buffer at $15^{\circ} \mathrm{C}$. Duplicate $40-\mu \mathrm{l}$ samples were placed into tubes containing $(a) 4.0 \mathrm{ml}$ of assay buffer at $15^{\circ} \mathrm{C},(b)$ $4.0 \mathrm{ml}$ of buffer at $15^{\circ} \mathrm{C}$ plus $0.167 \mu \mathrm{M}$ unlabeled insulin, and (c) $4.0 \mathrm{ml}$ of buffer at $15^{\circ} \mathrm{C}$ plus $25 \mu \mathrm{g} / \mathrm{ml}$ of purified IgG from serum B-2. At intervals, duplicate sets of tubes were sedimented, the supernate was removed, and the radioactivity in the cell pellet was counted. The radioactivity on the cells expressed as a percent of the radioactivity present at $\mathbf{T}=0$, is listed as a function of the time elapsed after dilution. The IgG was prepared by diethylaminoethyl (DEAE) cellulose fractionation of a resuspended $33 \%$ ammonium sulfate precipitate of serum (3). After $30 \mathrm{~min}$ of preincubation at $15^{\circ} \mathrm{C}$ with $2 \times 10^{8} \mathrm{IM}-9$ lymphocytes in a parallel experiment, this concentration of IgG caused an $80 \%$ inhibition of ${ }^{125}$ I-insulin binding (data not shown). 
of insulin binding to its receptor (12). The effect of serum pretreatment on dissociation of insulin subsequently bound to the cell was also assessed. Cells were first treated with serum or buffer, and then allowed to bind labeled hormone, after which dissociation of tracer was measured by dilution of cells in a large excess of buffer as above. In addition, the effect of unlabeled insulin on dissociation of tracer by dilution was determined (12). Pretreatment of cells with sera B-1, B-3, and the lower concentration of B-2 (which produced comparable degrees of insulin binding inhibition) had no significant effect on spontaneous dissociation of ${ }^{125} \mathrm{I}$-insulin at $15^{\circ} \mathrm{C}$ (Fig. 10). The higher concentration of serum B-2 produced a small $(15-20 \%)$ but highly reproducible effect on spontaneous dissociation. On the other hand, preincubation with each serum caused unlabeled insulin to be less effective in accelerating the dissociation of bound ${ }^{125}$ I-insulin from these cells. This effect was most pronounced with serum B-3 and with the higher concentration of B-2. Treatment with serum B-2 caused a rightward shift in the dose-response curve for insulin-induced acceleration of insulin dissociation, whereas treatment with sera B-1 and B-3 caused less enhancement of dissociation at each concentration of insulin (Fig. 11).

\section{DISCUSSION}

Peptide hormones and neurotransmitters initiate their actions through binding to specific receptors on the cell membrane (15). Defects at the level of the receptor would be expected to influence hormone action, and such defects might be expected to arise from a wide variety of possible mechanisms, both intrinsic and extrinsic to the cells in question. An interesting new mechanism by which receptor dysfunction may arise is the development of autoantibodies directed against specific membrane receptors (16). Such antireceptor antibodies are currently being

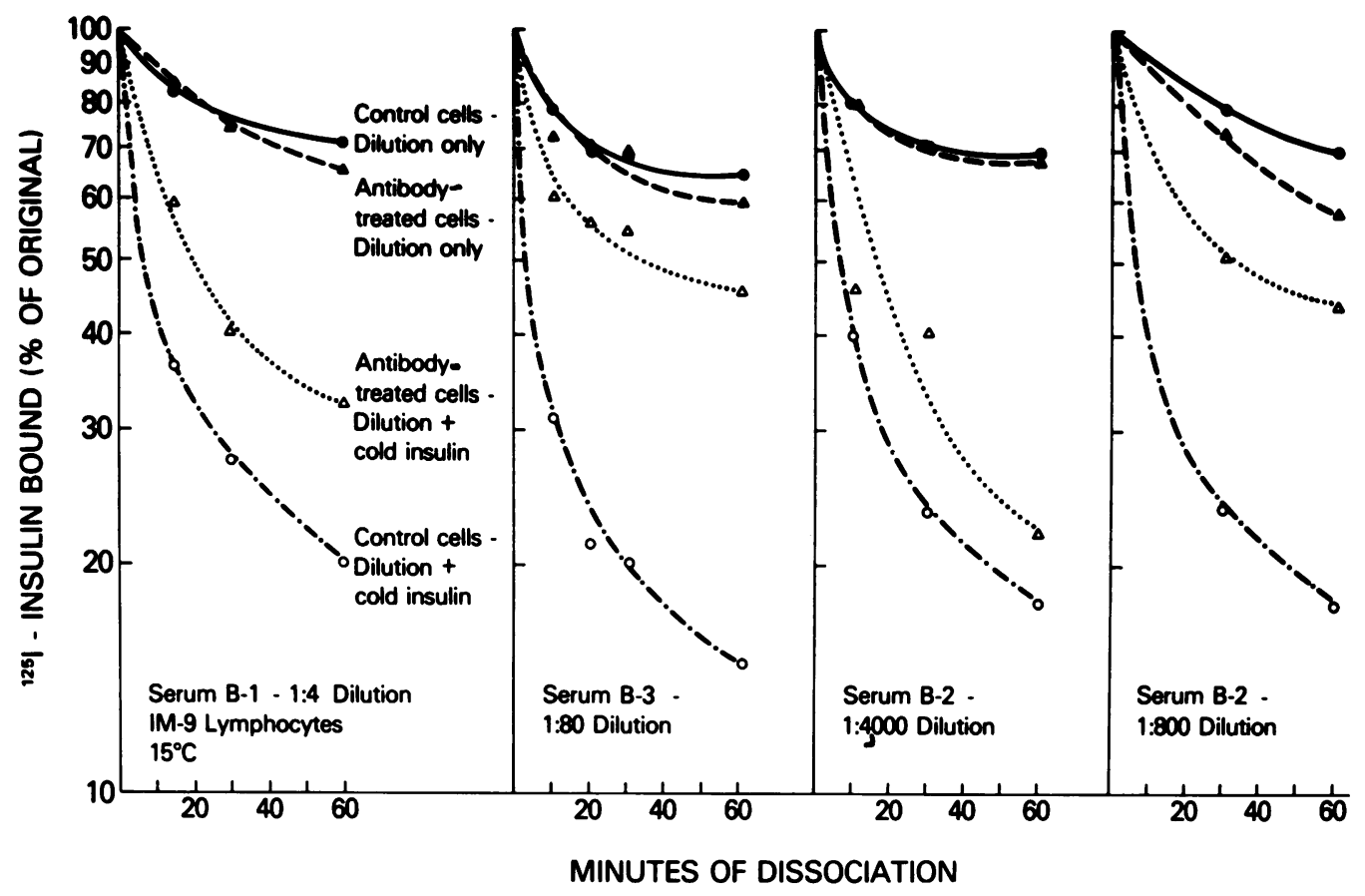

FIGURE 10 Effect of antireceptor antibody on dissociation of ${ }^{125}$ I-insulin from IM-9 lymphocytes. IM-9 cells were pretreated with serum or buffer, washed, and then incubated with ${ }^{125} \mathrm{I}$-insulin at $15^{\circ} \mathrm{C}$, in the presence and absence of $10 \mu \mathrm{g} / \mathrm{ml}$ of unlabeled insulin, as described in the legend to Fig. 8. After $90 \mathrm{~min}$ of incubation, 1-ml samples were removed, the cells were sedimented at $4^{\circ} \mathrm{C}$, and then resuspended in $1 \mathrm{ml}$ of fresh buffer at $15^{\circ} \mathrm{C} .40-\mu \mathrm{l}$ samples were then transferred to a series of tubes that contained $4 \mathrm{ml}$ of buffer in the presence and absence of unlabeled insulin $\left(1.67 \mu \mathrm{M}, 15^{\circ} \mathrm{C}\right)$. At intervals, duplicate tubes of each set were sedimented, the supernate was removed, and the radioactivity in the cell pellet was counted. The radioactivity on the cells expressed as a percent of the radioactivity present at $\mathbf{T}=0$ is plotted as a function of the time elapsed after dilution. Each point is the mean of duplicates; duplicates differed by $<5 \%$. In each case, nonspecific binding (i.e., that which bound in the presence of $10 \mu \mathrm{g} / \mathrm{ml}$ insulin in the original association) was subtracted to yield specific counts. 


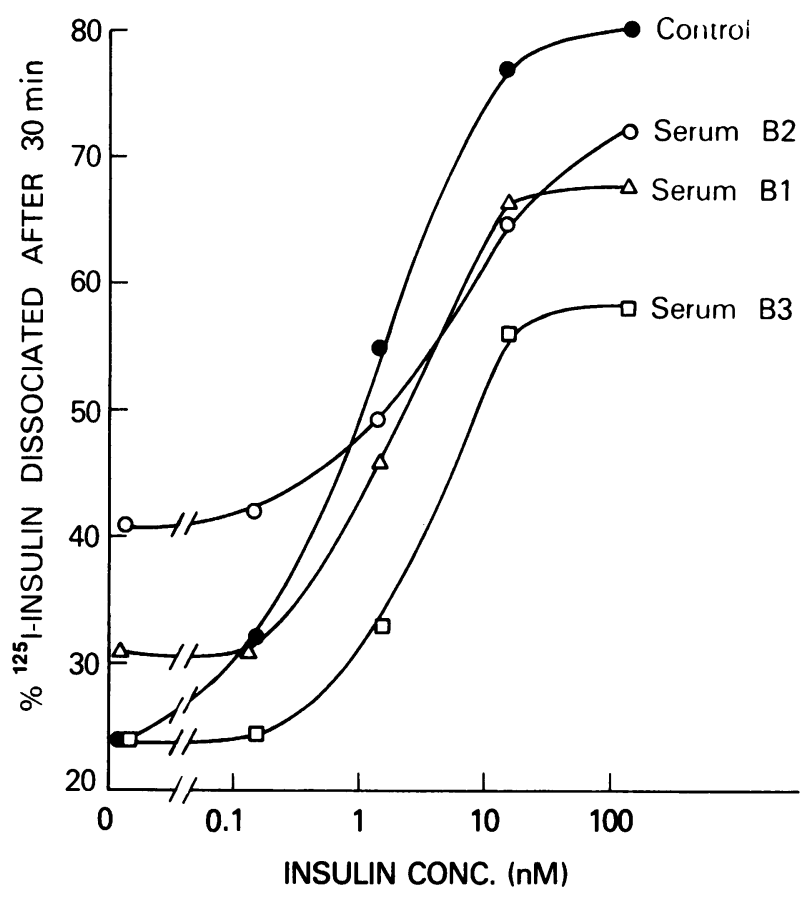

FIGURE 11 Dose response for insulin-induced negative cooperativity in IM-9 cells pretreated with antireceptor antisera. The experiment was performed as in the legend to Fig. 10, with the exceptions that $(a)$ dissociations were performed in the presence of varying concentrations of unlabeled insulin as seen on the horizontal axis; $(b)$ data from a single $(30 \mathrm{~min})$ time-point were obtained; $(c)$ the data are expressed as the percent of specifically bound insulin which is dissociated at each insulin concentration (conc.); and $(d)$ the sera employed were B-1 (1:4 dilution), B-2 (1:4,000 dilution), and $\mathrm{B}-3$ (1:80 dilution).

proposed in the pathogenesis of three diseasesmyasthenia gravis, Graves' disease, and the syndrome of extreme insulin resistance with acanthosis nigricans, type $B(1,5,6)$.

In the latter syndrome, we have previously characterized the circulating immunoglobulins that bind to and block the membrane receptors for insulin $(2,3)$. In this report, we analyze in depth the effect of these antibodies on ${ }^{125}$ I-insulin binding, so as to better understand the nature of their interaction with the insulin receptor.

With insulin receptors on a human lymphoblastoid cell line (IM-9) as a model, inhibition induced by undiluted serum is rapid, with the two highest titered sera causing nearly maximal inhibition after $<5 \mathrm{~min}$ exposure to the cells (Fig. 1). In addition, the extent of inhibition is quite marked, with at least $95 \%$ of specific insulin binding being blocked after incubation with serum B-2. Maximal inhibition may not have been reached after $3 \mathrm{~h}$, particularly for sera B-1 and B-3.

Studies with appropriately diluted serum samples permitted comparative studies of time-course and temperature dependence of the inhibitory effect (Fig. 2). They indicate similar rates of onset of inhibition, and a single disparity with regard to temperature dependence of the effect. That is, whereas sera B-2 and B-3 produced maximum inhibition of insulin binding when exposed to cells at $37^{\circ} \mathrm{C}$, serum $\mathrm{B}-1$ was maximally effective at $22^{\circ} \mathrm{C}$. This strongly suggests that serum B-1 recognizes a binding determinant on the membrane different from those recognized by sera B-2 or B-3. It should also be noted that the temperature dependence of antibody effect for all three sera is clearly different from that for insulin binding to its receptor (7). At steady state, insulin binding is characteristically greater at $4^{\circ}$ than at $22^{\circ} \mathrm{C}$ and this in turn is greater than that at $37^{\circ} \mathrm{C}$.

In contrast to the rate of onset of inhibition, the rate of return of binding when cells are washed and placed in fresh buffer is very slow (Fig. 3). This presumably reflects slow dissociation of bound antibody, and may be the consequence of bivalent binding of antibody to clustered insulin receptors. This slow dissociation rate, which differs markedly from that of insulin, permits completion of the insulin binding assay $\left(15^{\circ} \mathrm{C}, 90 \mathrm{~min}\right)$ under conditions in which antibody effect remains constant. Exposure of cells to acid conditions known to elute cell-bound antibodies produced a major restoration of insulin binding, confirming the reversible nature of the antibody effect.

Analysis of steady-state insulin binding to cells pretreated with antireceptor antibodies suggests combined effects on both receptor affinity and total $R_{0}$. With serum B-1, nearly all of the binding inhibition may be explained by reduction of $R_{0}$, with little or no effect on receptor affinity for insulin. In contrast, after exposure to sera B-2 and B-3, both $R_{0}$ and affinity are reduced, but major reductions of receptor affinity predominate. It should be noted that reductions in $R_{0}$ and affinity in this analysis may be considered analogous to the effects produced by "noncompetitive" and "competitive" inhibitors, respectively, in the terminology of enzymology. Although mechanistic explanations for the nature of these effects on $R_{0}$ and affinity are speculative, we might envisage a reduction of $R_{0}$ to be the result of an essentially irreversible occupation of the receptor in such a way as to completely prevent insulin binding. On the other hand, a reduction of receptor affinity might result from antibody binding in such a way as to sterically hinder, but not entirely prevent, the binding of insulin. Combinations of effects on $R_{0}$ and affinity might result from heterogeneous antibody populations or from binding to intermediate sites.

Direct study of insulin association and dissocia- 
tion kinetics with cells pretreated with antireceptor antibodies permitted further analysis of the mechanism by which reduction of affinity for insulin was produced. In this case, as with the analysis of steadystate binding (vide supra), a combination of effects is apparent. Thus, after exposure to serum B-2, we observe slower insulin association rate on the basis of reduced association rate constant, as well as enhanced dissociation rate of insulin from antibodytreated cells under the same conditions. The effects of these antibodies on insulin receptor affinity appear to be complex, and indeed may vary among sera, and with different concentrations of the same sera. It should be stressed, however, that the major mechanism by which these antibodies appear to reduce receptor affinity for insulin is by reducing the association rate constant for insulin binding. This is clearly distinguished from the mechanism by which insulin reduces the affinity of its receptor (i.e., negative cooperativity), which is through an acceleration of the dissociation rate.

The ability of insulin to induce site-site interactions of the negatively cooperative type is a characteristic feature of insulin receptors (12). It is of interest that treatment of cells with antireceptor antibodies appears to reduce the capacity of insulin to induce this phenomenon. Evidence on this point derives from both steady-state and kinetic data. First, analysis of steady state data for ${ }^{125}$ I-insulin binding to control cells with the "average affinity profile" (vide supra) is consistent with a fall in average receptor affinity with increasing receptor occupancy. This finding reflects negatively cooperative site-site interactions between insulin receptors, as demonstrated by direct kinetic experiments (12). When cells are treated with antireceptor antibodies, average affinity for insulin is reduced at low levels of receptor occupancy, with little or no reduction in affinity observed at the highest degrees of receptor occupancy. Thus, the degree to which receptor affinity is reduced with progressive occupancy by insulin is less marked in antibody-treated than in control cells. Further, treatment with each serum reduced the extent of negative cooperativity as determined by the direct kinetic experiment of De Meyts et al. (12). The dissociation of ${ }^{125} \mathrm{I}$-insulin from cells pretreated with antireceptor antibody was accelerated to a lesser degree by unlabeled insulin than was the dissociation of ${ }^{125} \mathrm{I}$-insulin from untreated cells. This resistance to the induction of negative cooperativity by insulin was seen over a wide range of insulin concentrations.

Thus, both kinetic and steady-state data suggest that antireceptor antibody binding reduces the capacity for negative cooperativity induced by insulin, although the mechanism of this effect may be complex. Several speculations seem reasonable. First, because negative cooperativity induced by insulin is a function of insulin binding to its receptor, we would expect inhibition of insulin binding caused by antibody to inhibit the ability of a given amount of insulin to induce negative cooperativity. According to this model, any insulin that did bind would induce cooperativity to the usual extent. Our current inability to analyze the dissociation data in a precise quantitative manner makes it difficult to compare the extent of binding inhibition with the reduction of cooperativity, and thereby determine whether binding inhibition is the sole mechanism for reduced cooperativity. However, binding of antireceptor antibodies might additionally impair the capacity for negative cooperativity by inducing slight alterations in the conformation of the receptor or its subunits (17). It is important to note that the addition of antibody to the diluting media in a concentration sufficient to reduce tracer insulin binding by $80 \%$ did not induce an acceleration in the dissociation rate of insulin bound to control cells, i.e., unlike insulin, the binding of antibody to the membrane did not cause cooperative interactions of the negative type between insulin receptors. ${ }^{2}$

Thus, detailed analysis reveals that the inhibition of insulin binding caused by antireceptor antibodies may involve a variety of mechanisms. These include competitive occupancy of receptor sites, alteration of insulin association and dissociation kinetics, and interference with site-site interactions between receptors. Further use of these antibodies as probes of the insulin receptor may exploit one or more of these interesting effects. In addition, these antibodies may serve as a model for other studies of antibody effects on the interaction of ligands with important cell membrane receptors.

\section{ACKNOWLEDGMENT}

The authors wish to acknowledge Mrs. J. Smith and Mrs. C. Shinn for their excellent secretarial assistance.

\section{REFERENCES}

1. Kahn, C. R., J. S. Flier, R. S. Bar, J. A. Archer, P. Gorden, M. M. Martin, and J. Roth. 1976. The syndromes of insulin resistance and acanthosis nigricans: insulinreceptor disorders in man. N. Engl. J. Med. 294: 739-745.

2. Flier, J. S., C. R. Kahn, J. Roth, and R. S. Bar. 1975. Antibodies that impair insulin receptor binding in an unusual diabetic syndrome with severe insulin resistance. Science (Wash. D. C.). 190: 63-65.

3. Flier, J. S., C. R. Kahn, D. B. Jarrett, and J. Roth. 1976. Characterization of antibodies to the insulin receptor: a

${ }^{2}$ It has recently been demonstrated (Jarrett et al., manuscript in preparation) that very high concentrations of this antibody are able to induce negative cooperativity. 
cause of insulin resistant diabetes in man. J. Clin. Invest. 58: 1442-1449.

4. Jarrett, D. B., J. Roth, C. R. Kahn, and J. S. Flier. 1976. Direct method for detection and characterization of cell surface receptors for insulin by means of ${ }^{125}$ I-labeled autoantibodies to receptors. Proc. Natl. Acad. Sci. U. S. A. 73: 4115-4119.

5. Smith, B. R., and R. Hall. 1974. Thyroid stimulating immunoglobulins in Graves' disease. Lancet. 2: 427-431.

6. Lindstrom, J. A., M. E. Seybold, V. A. Lennon, S. Whittingham, and D. O. Duane. 1976. Anti-acetylcholine receptor antibody in myasthenia gravis: incidence, clinical correlates, and usefulness as a diagnostic test. Neurology. 26: 1054-1059.

7. Gavin, J. R., III, P. Gorden, J. Roth, J. A. Archer, and D. N. Buell. 1973. Characteristics of the human lymphocyte insulin receptor. J. Biol. Chem. 248: 2202-2207.

8. Kahn, C. R., P. Freychet, J. Roth, and D. M. Neville, Jr. 1974. Quantitative aspects of the insulin receptor interaction in liver plasma membranes. J. Biol. Chem. 249: 2249-2257.

9. Gliemann, J., and S. Gammeltoft. 1974. The biological activity and the binding affinity of modified insulins determined on isolated rat fat cells. Diabetologia. 10: 105-113.
10. Freychet, P., J. Roth, and D. M. Neville, Jr. 1971. Monoiodoinsulin: demonstration of its biological activity and binding to fat cells and liver membranes. Biochem. Biophys. Res. Commun. 43: 400-408.

11. Scatchard, G. 1949. The attraction of proteins for small molecules and ions. Ann. N. Y. Acad. Sci. 51: 660-672.

12. DeMeyts, P., A. R. Bianco, and J. Roth. 1976. Site-site interactions among insulin receptors: characterization of the negative cooperativity.J. Biol. Chem. 251: 1877-1888.

13. DeMeyts, P., and J. Roth. 1975. Cooperativity in ligand binding: a new graphic analysis. Biochem. Biophys. Res. Commun. 55: 1118-1125.

14. Ishizaka, T., and K. Ishizaka. 1974. Mechanisms of passive sensitization. IV. Dissociation of IgE molecules from basophil receptors at acid pH. J. Immunol. 112: 10781084.

15. Kahn, C. R. 1976. Membrane receptors for hormones and neurotransmitters. J. Cell Biol. 70: 261-286.

16. Carnegie, P. R., and I. R. Mackay. 1975. Vulnerability of cell-surface receptors to autoimmune reactions. Lancet. 2: 684-687.

17. Ginsberg, B. H., C. R. Kahn, J. Roth, and P. DeMeyts. 1976. Insulin-induced dissociation of its receptor into subunits: Possible molecular concomitant of negative cooperativity. Biochem. Biophys. Res. Commun. 73: 1068-1074. 